\title{
EVALUATION OF THE AMMONIA AIR POLLUTION AND CLIMATIC FACTORS INTERACTIONS, CASE STUDY 2008 BACAU CITY ROMANIA
}

\author{
DOINA CAPȘA ${ }^{1}$, NARCIS BÂRSAN ${ }^{2 *}$, VALENTIN NEDEFF ${ }^{2}$, EMILIAN \\ MOȘNEGUȚU ${ }^{2}$, DANA CHIȚIMUȘ² \\ 1"Vasile Alecsandri" National College Bacau, Vasile Alecsandri 37, Bacau, 600011, \\ Romania \\ 2 “Vasile Alecsandri” University of Bacau, Calea Marasesti 156, Bacau, 600115, Romania
}

\begin{abstract}
Atmospheric pollution present interest for monitoring and analysis when one or more substances or mixture of pollutants are present in the atmosphere in quantities or for a period that can be dangerous for humans, animals or plants and contribute to endangering the activity or welfare of persons. The present research was aimed to establish a link between meteorological factors (temperature, wind, atmospherically humidity, solar radiation, air pressure) and the ammonia air pollutant. Particularities of research methodology consisted in establishing a connection between meteorological factors in Bacau area and its air quality, taking into account both direct and inverse effects induced by geographical complexity and economic activities. The correlations between ammonia air pollution and analyzed climatic factors variation were realized by graphical interpretations and observing the appropriate links of dependency. In one of the case (2008.08.20) a better dispersion of pollutants occurs in the case of sunshine duration over a longer period, without or with low nebulosity.
\end{abstract}

Keywords: atmospheric pollution, ammonia air pollutant, meteorological factors

\section{INTRODUCTION}

The environment is characterized by some natural, economic, social industrial and political activities that involve all participants equally and that can include demographic data, lifestyle and economic cycles etc. Air quality is determined by air emissions from stationary and mobile sources, as well as pollutants transport over long distances [1-9].

Air quality is determined by air emissions from stationary and mobile sources, as well as pollutants transport over long distances [10-12].Atmospheric pollution present interest for monitoring and analysis when one or more substances or mixture of pollutants are present in the atmosphere in amounts or for a period that can be dangerous for humans, animals or plants and contribute to endangering the activity or welfare of persons [13-15].Pollution effects can be occurred through changes of all principal meteorological elements, decrease of solar radiations and increase of temperature $[2-6,16,17]$.

European Environmental Agency (EEA)coordinates air quality activities, analyzing the data collected by 7500 monitoring stations in Air Base database [14, 18].One of the fundamental roles of EEA is to sustain environmental policy and results reporting on about the implementation of EU environmental legislation in all Member States $[11,14,18]$.

\footnotetext{
${ }^{*}$ Corresponding author, email: narcis.barsan@ub.ro
}

(C) 2016 Alma Mater Publishing House 
On Romanian territory are 11 human agglomerations in which management and air quality assessment systems exist and 8 regions for air quality management according to O.M. 745/2002. At national level 142 continuous monitoring stations of air quality are operating. National Network of Air Quality Monitoring comprises 41 local centers. In according to Law 104/2011 on ambient air quality, responsibility for monitoring of ambient air quality in Romania is owed by environmental protection authorities. Pollutants monitored, measurement methods, limit values, alert thresholds and information and criteria location of monitoring points are established by national legislation on air protection and are in agreement with European regulations [4, 11, 18-21].

Air quality in human settlements is determined by measuring (hourly, daily or monthly) average concentrations of different pollutants. These values are then compared with limit values or, as appropriate, the maximum allowable concentrations provided by the legislation in force [21-23].Local air quality supervision is done using monitoring stations by measuring the concentrations of pollutants $[11,24]$ : common $\left(\mathrm{SO}_{2}, \mathrm{NO}_{2}, \mathrm{NH}_{3}\right.$, Particulate Matter), in most industrial area and/or urban; specific $\left(\mathrm{HCl}\right.$, phenols, aldehydes, $\mathrm{Cl}, \mathrm{H}_{2} \mathrm{~S}, \mathrm{CS}_{2}, \mathrm{~F}, \mathrm{H}_{2} \mathrm{SO}_{4}$, heavy metals: $\mathrm{Pb}$, Cd).

Pollutants dispersion is determined by the climatic factors that influences the air mass, especially in the troposphere. The study of diffusion and atmospheric pollutants reactions involves quality, quantity and emissions distribution knowledge, as well as local atmospheric conditions. The aim of the research is to establish a research methodology aimed at linking meteorological factors (temperature, wind, atmospherically humidity, solar radiation, nebulosity, pressure, precipitation and fog phenomenon) [2-6, 25] and ammonia in Bacau district, taking into account the direct and inverse effects of its geographical complexity and economic activities [7, 26].

\section{EXPERIMENTAL SETUP}

Bacau city is the capital of Bacau district and it is located in north east of Romania with $46^{\circ} 35^{\prime} \mathrm{N}, 26^{\circ} 55^{\prime} \mathrm{E}$ coordinates. Its surroundings are a vast and complex geographic area with many specific particularities. The slopes on the left Siret river bank (alongside of Prut) always steep and high, are accompanied by the fragments of terraces, and those on the right subsided, with a large terraces.

Bacau is located just $9.6 \mathrm{~km}$ upstream of the confluence of Siret - Bistrita, at an altitude of 160.056 ma.s.1. Bacau climate is temperate - continental with cold winters and hot dry summers. This climate type is a result of complex natural and anthropogenic factors.

The city has a vital role in creating their own mesoclimate by a series of constant factors and by means of some secondary factors (artificial warming, atmosphere pollution) [27, 28]. Presence of confluence area and Bistrita river corridor favors the channeling of air masses along its in meteorological conditions characterized by winds from south and southeast, alternated with period of calm [27] (average wind speeds $<1.5 \mathrm{~m} / \mathrm{s}$ ), status that characterized area much of the year and frequent occurrence of thermal inversion situations [4].

Thermal inversions may occur before the warm fronts are coupled with low wind speeds. In this situation, air affected by the emissions of economic agents located on industrial platform from southern city, is engaging in this direction.

Two automatic monitoring stations (BC1 and $\mathrm{BC} 2)$ are operative in Bacau. $\mathrm{BC} 1$ is located in city center, according to the methods for positioning urban stations of air quality monitoring. European road E85 (crossing the city from north to south), by the absence of bypasses, causes diminishing of air quality in urban central area.BC2 is located near the corridor at the distance of about $2 \mathrm{~km}$ from the industrial area [2-6]. Meteorological factors as well as ammonia air quality indexes exceeding threshold alert and maximum allowable limits [2-6] were considered in this study.

Meteorological elements vary in time and space. A single point of measurement provides information for a small area, of approximately $40 \mathrm{~km}^{2}$. The basic unit of observation network is the meteorological station. Bacau district meteorological station is part of the meteorological national system and has an operating system that provides data in meteorological world system.

Processing the as-obtained data by surface measurements from meteorological stations is done through software developed within SIMIN project. The aim of this software is collection, validation and distribution of all surface 
observations throughout the country. It is organized on three levels: local (meteorological station), regional and central [4].

Data on meteorological elements were obtained from Bacau meteorological station, automatic of Vaisala MAWS 301 type. According to standards operative conditions, measurements were performed every hour. For wind element measuring is made in second by second, data are then vectorial summed on intervals of 60 seconds, 2 and 10 minutes [2-6]. Air quality indices monitored by Bacau 1 automatically station (BC1) and Bacau 2 (BC2) refer to the following pollutants: nitrogen oxides $\mathrm{NO}_{\mathrm{x}}\left(\mathrm{NO} / \mathrm{NO}_{2}\right)$; benzene $\mathrm{C}_{6} \mathrm{H}_{6}$; ammonia $\mathrm{NH}_{3}$ [4] .

Quality indices for air in protected areas are provided in Standard 12574-87. This refers to atmospheric air and establishes maximum allowable concentrations for some pollutants in the area of protected zones. According STAS 1.2574-87 maximum allowed concentration (MAC) in protected areas, for daily average sample, ammonia index, is $0.100 \mathrm{mg} / \mathrm{m}^{3}$. Maximum allowed concentration for ammonia in protected area is $0.30 \mathrm{mg} / \mathrm{m}^{3}$, and the alert threshold is $0.21 \mathrm{mg} / \mathrm{m}^{3}$ [4].

Generally, low concentrations of pollutants are favored by the wind and unstable conditions from the lower layer of the atmosphere. In contrast, high pollutants concentrations are supported by dense and persistent fog, no wind or thermal inversion. In this regard have been drawn maps for Bacau area that highlight sources distribution; sampling point's distribution; frequency distribution of the alert threshold and maximum allowable limit [4].

\section{RESULTS AND DISCUSSION}

In 2008 the ammonia analyzer of BC1 station did not work by technical reasons. Recording on the ammonia concentration from 2008.08.13 was performed by Bacau Environmental Protection Regional Agency, recording a maximum concentration of $1.964 \mathrm{mg} / \mathrm{m}^{3}$ between the hours $10: 34-11: 04$ at the coordinate point $46^{\circ} 33.994^{\prime} \mathrm{N}$, $26^{\circ} 54.184^{\prime} \mathrm{E}$. Other measured values have been of $0.398 \mathrm{mg} / \mathrm{m}^{3}$ between the hours 09:27 - 09:57 at the coordinate point $46^{\circ} 32.552 ' \mathrm{~N}, 26^{\circ} 55.010^{\prime} \mathrm{E}$ and of $0.511 \mathrm{mg} / \mathrm{m}^{3}$ (hours $10: 22-10: 52$ ) at the coordinate point $46^{\circ} 31.993{ }^{\prime} \mathrm{N}$, $26^{\circ} 54.907 ' \mathrm{E}[4]$.

Ammonium trend along 24 hours (starting from Aug 13, 2008) is shown together with the trend registered by BC2 station and meteorological parameters in Figures 1 and 2.

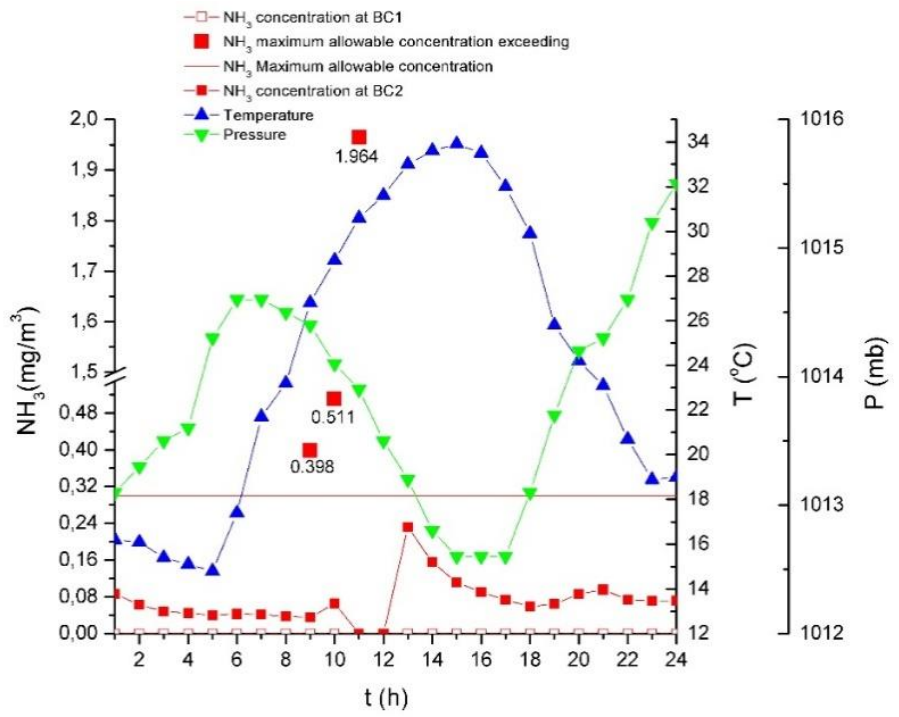

Fig. 1. Variation of ammonia $\left(\mathrm{NH}_{3}\right)$ concentration in the air, air temperature $(\mathrm{T})$ and atmospheric pressure $(\mathrm{P})$ over 24 hours on 13.08.2008 at air quality monitoring station BC 2 (Izvoare) [4]. 


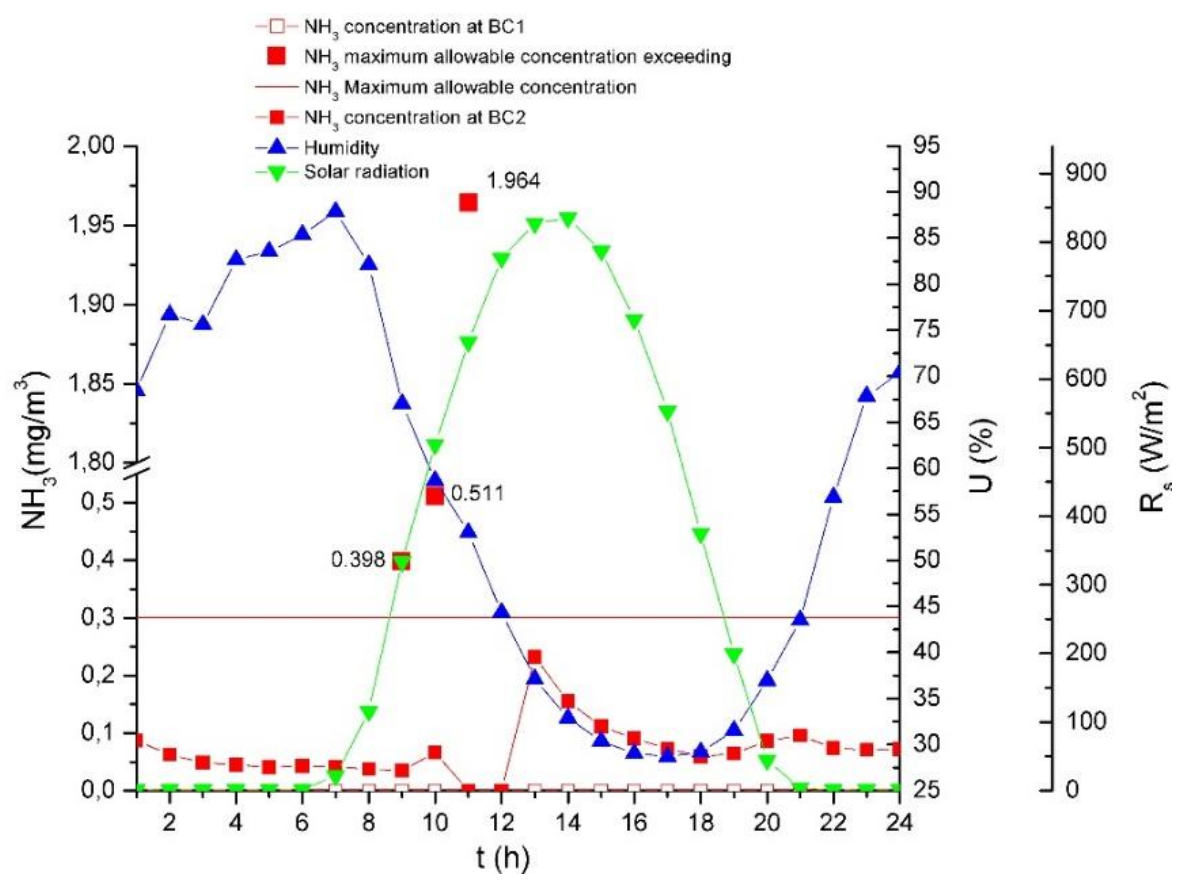

Fig. 2.Variation of ammonia $\left(\mathrm{NH}_{3}\right)$ concentration in the air, the humidity (U) and solar (RS) over 24 hours on 13.08.2008 at air quality monitoring station BC 2 (Izvoare) [4].

From analysis of ammonia concentration variation registered at air quality monitoring station BC2 (Izvoare) at 2008.08.13correlated with the meteorological parameters (air temperature variation, wind, atmospheric pressure, air humidity and solar radiation) it was identified that over 24 hours has been registered an increase of ammonia concentration between hours 09:00 - 17:00, with a maximum at 13:00, that exceeded alert threshold $\left(0.21 \mathrm{mg} / \mathrm{m}^{3}\right)$ reaching a value of $0.231 \mathrm{mg} / \mathrm{m}^{3}[4]$.

Maximum concentration of the day was $1.964 \mathrm{mg} / \mathrm{m}^{3}$, reached between hours 10:34 - 11:04, measured in coordinate point $46^{\circ} 33.994^{\prime} \mathrm{N}, 26^{\circ} 54.184^{\prime} \mathrm{E}$. This correspond to an excess of 6.5 times compared to maximum allowable value.

During this time, atmospheric pressure shown insignificant variations, with similar to normal values of 1013.5 mbar at hour 11:00, and air temperature and solar radiation increased, with a maximum between hours 13:00 14:00 [4]. Between the hours 13:00 - 17:00, pollutant concentration decreased, this corresponding to a significant decrease in atmospheric humidity and solar radiation.

The wind can be characterized as weak to moderate with average speeds until $3.3 \mathrm{~m} / \mathrm{s}$ from south-eastern sector, which determined a movement of pollutant toward central area of city and a rapid dispersion, registered at BC2 station over 4 hours $(10: 00-14: 00)[4]$.

Analyzing the above graphs and synoptic situations of the day it was found that on the background of warm weather determined by a wet tropical air mass, when temperature - humidity indices (T.H.I) has reached critical threshold of 80 units.

Subjected area study is located at the back periphery of the dispersion area home Icelandic depression. This caused a movement of the air mass from south-eastern sector, direction that involving the ammonia movement to habitable area of the city, whose dispersion was proportional with wind speed [4]. 


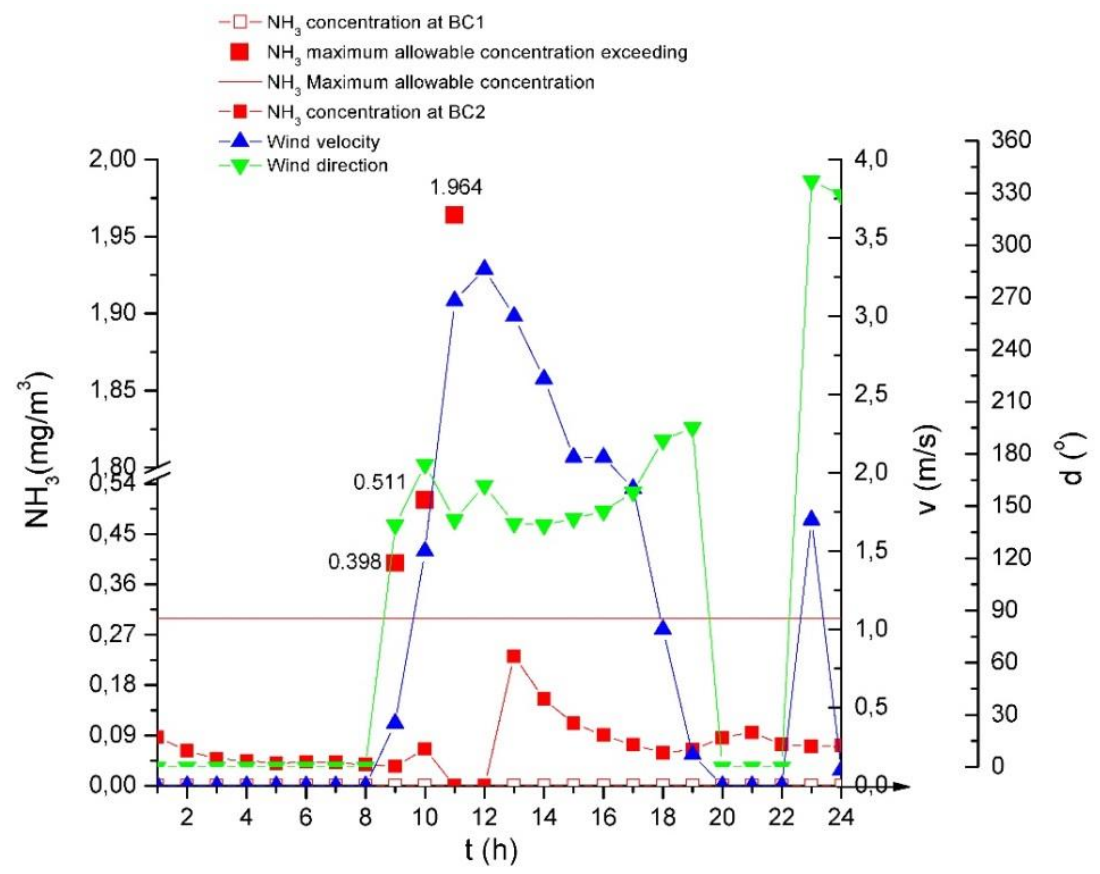

Fig. 3.Variation of ammonia $\left(\mathrm{NH}_{3}\right)$ concentration in the air, the wind speed (v) and direction (d) its over 24 hours on 13.08.2008 at air quality monitoring station BC 2 (Izvoare) [4].

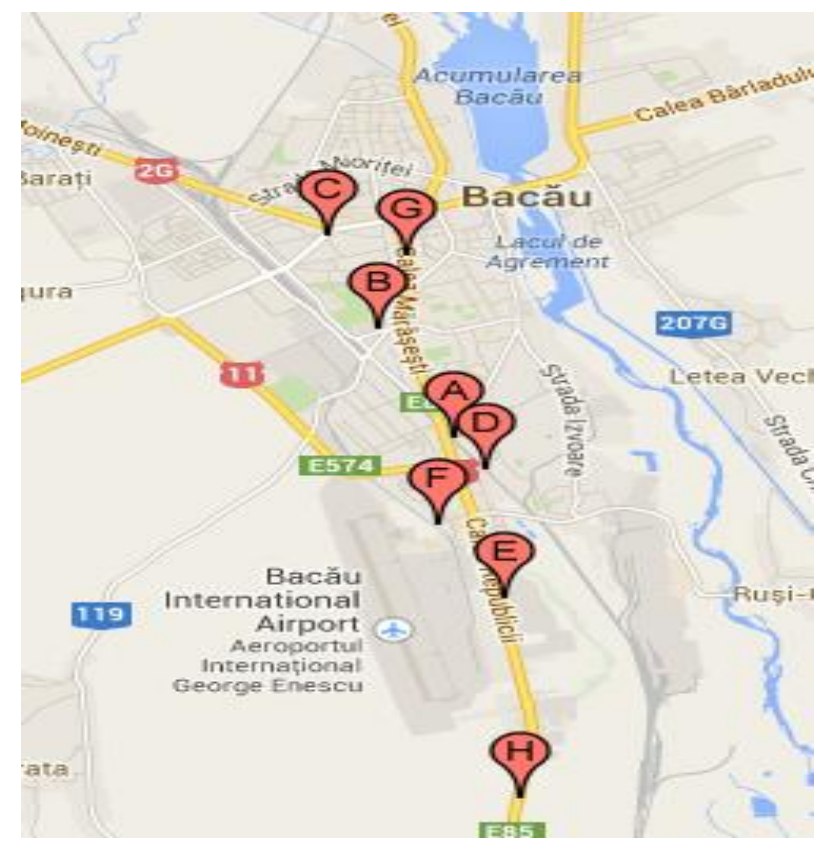

Fig.4. Distribution points of the ammonia recording in 2008 [4]:

A - Bicaz street no. 138 (coordinate $\left.46^{\circ} 32.552^{\prime} \mathrm{N}, 26^{\circ} 55.010^{\prime} \mathrm{E}\right)$; B -Spiru Haretstreet no. 8

(coordinate $46^{\circ} 33.334^{\prime} \mathrm{N}, 26^{\circ} 54.515^{\prime} \mathrm{E}$ ), C - Oituz street no 23 (coordinate $46^{\circ} 33.994^{\prime} \mathrm{N}, 26^{\circ} 54.184 ' \mathrm{E}$ ), D Republicii street no.76 (coordinate $46^{\circ} 31.402^{\prime} \mathrm{N}, 26^{\circ} 55.331^{\prime} \mathrm{E}$ ), E - Calea Republicii street no. 189 (coordinate $\left.46^{\circ} 32.321^{\prime} \mathrm{N}, 26^{\circ} 55.209^{\prime} \mathrm{E}\right), \mathrm{G}$ - Mărășești street no. 2-4, (coordonate46³3.851'N, 2654.697'E), F - Aeroportul street no. 1 (coordinate $46^{\circ} 31.993^{\prime} \mathrm{N}, 26^{\circ} 54.907^{\prime} \mathrm{E}$ ), $\mathrm{H}-$ Bacau south limit, (coordinate $46^{\circ} 29.969^{\prime} \mathrm{N}$, $\left.26^{\circ} 55.433^{\prime} \mathrm{E}\right)$.

On 2008.08.20 Bacau Environmental Protection Regional Agency has registered a maximum ammonia concentration of $1.060 \mathrm{mg} / \mathrm{m}^{3}$ in coordinate point $46^{\circ} 32.321^{\prime} \mathrm{N}, 26^{\circ} 55.209 ' \mathrm{E}$, between hours 10:20 - 10:50, and in 
coordinate point $46^{\circ} 33.994{ }^{\prime} \mathrm{N}, 26^{\circ} 54.184^{\prime} \mathrm{E}$, the concentration measured was $0.380 \mathrm{mg} / \mathrm{m}^{3}$ between hours $09: 54-$ 10:24 [4].

From the analysis of Figure 4 it is observed that recording distribution points of maximum concentration for ammonia are along the European E85 road.

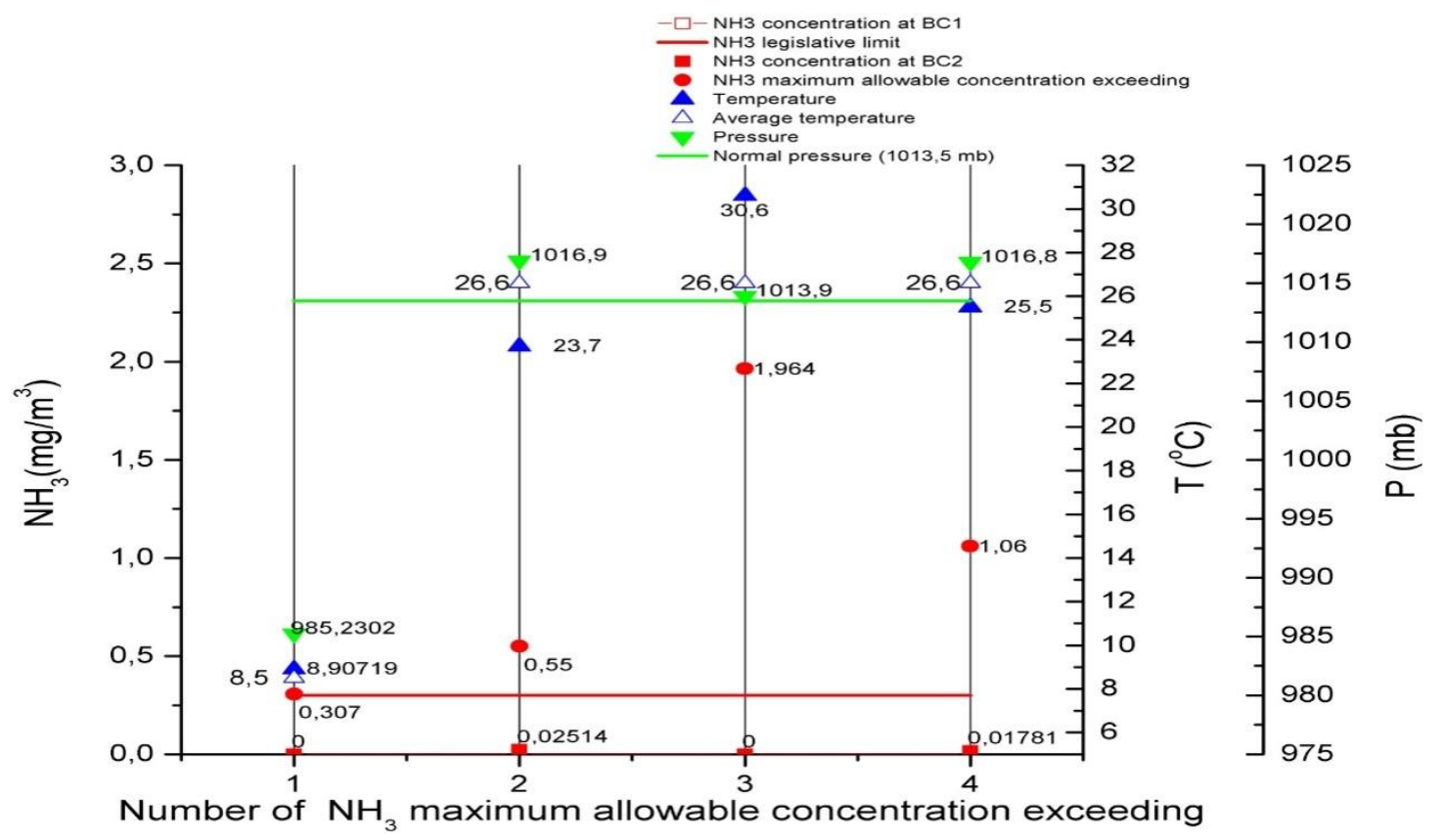

Fig. 5. Maximum allowable concentration overruns for ammonia $\left(\mathrm{NH}_{3}\right)$ in the air, air temperature $(\mathrm{T})$ and atmospheric pressure (P), in 2008 at the air quality monitoring station BC 2 (Izvoare) [4].

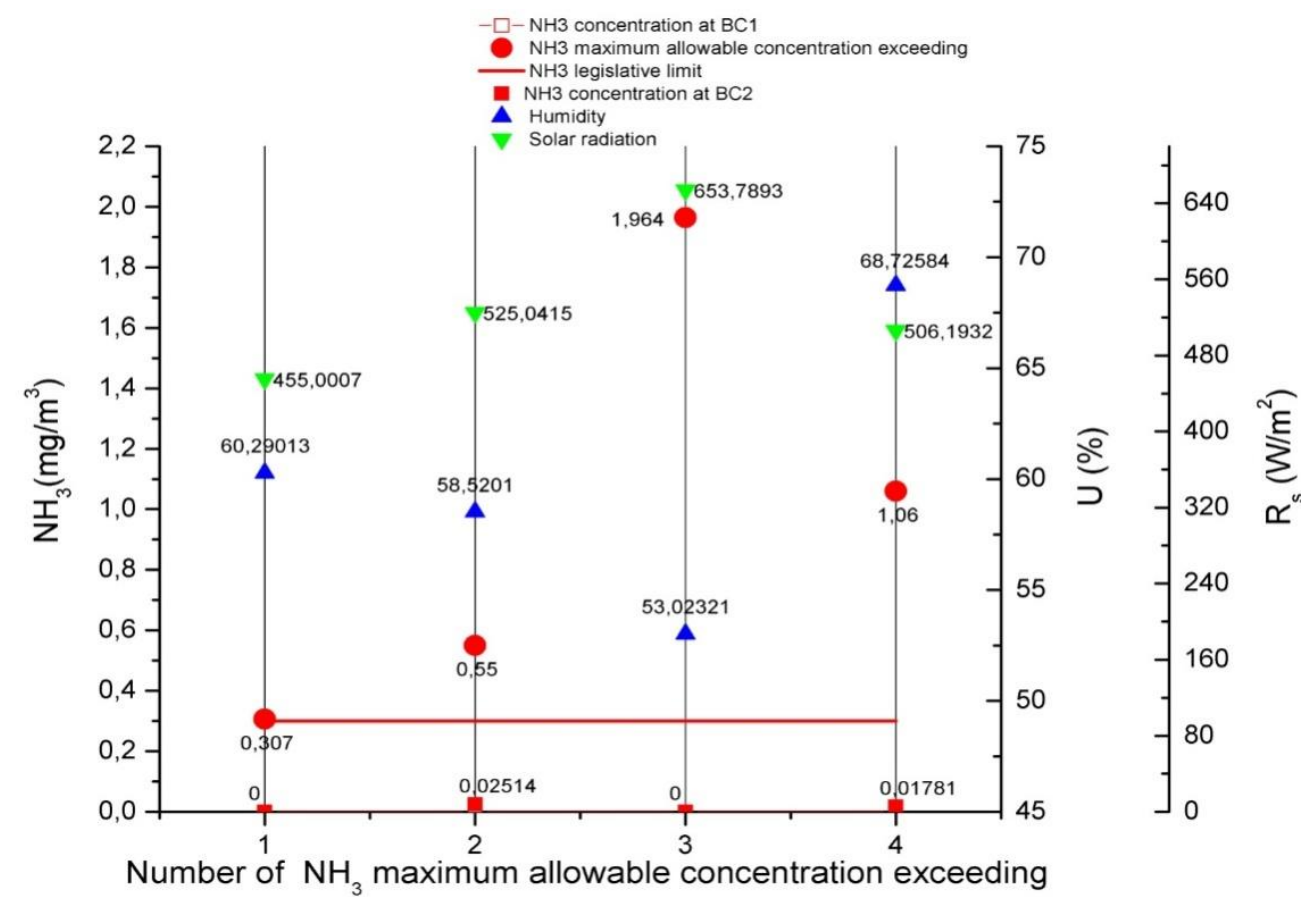

Fig. 6. Maximum allowable concentration overruns for ammonia $\left(\mathrm{NH}_{3}\right)$ in the air, atmospheric humidity (U) and solar radiation $\left(\mathrm{R}_{\mathrm{S}}\right)$ in 2008 at the air quality monitoring station BC 2 (Izvoare) [4]. 
The above interpretation can be transposed as a summative analysis in terms of correlation between ammonia pollutant and climatic factor analyzed (air temperature variation, wind, atmospheric pressure, air humidity and solar radiation). In 20084 overruns of maximum allowed concentration (MAC) to ammonia pollutant were observed. Their frequency was higher in summer, valuing 3 and only an overrun has been reported in cold season. Sampling point's pollutant is situated in central southern of the city.In Figure 5 is shown the graphic of MAC overruns in 2008, ammonia concentration values $\left(\mathrm{NH}_{3}\right)$ from air, air temperature $(\mathrm{T})$ and atmospheric pressure $(\mathrm{P})$ to air quality monitoring station BC2 (Izvoare) [4].

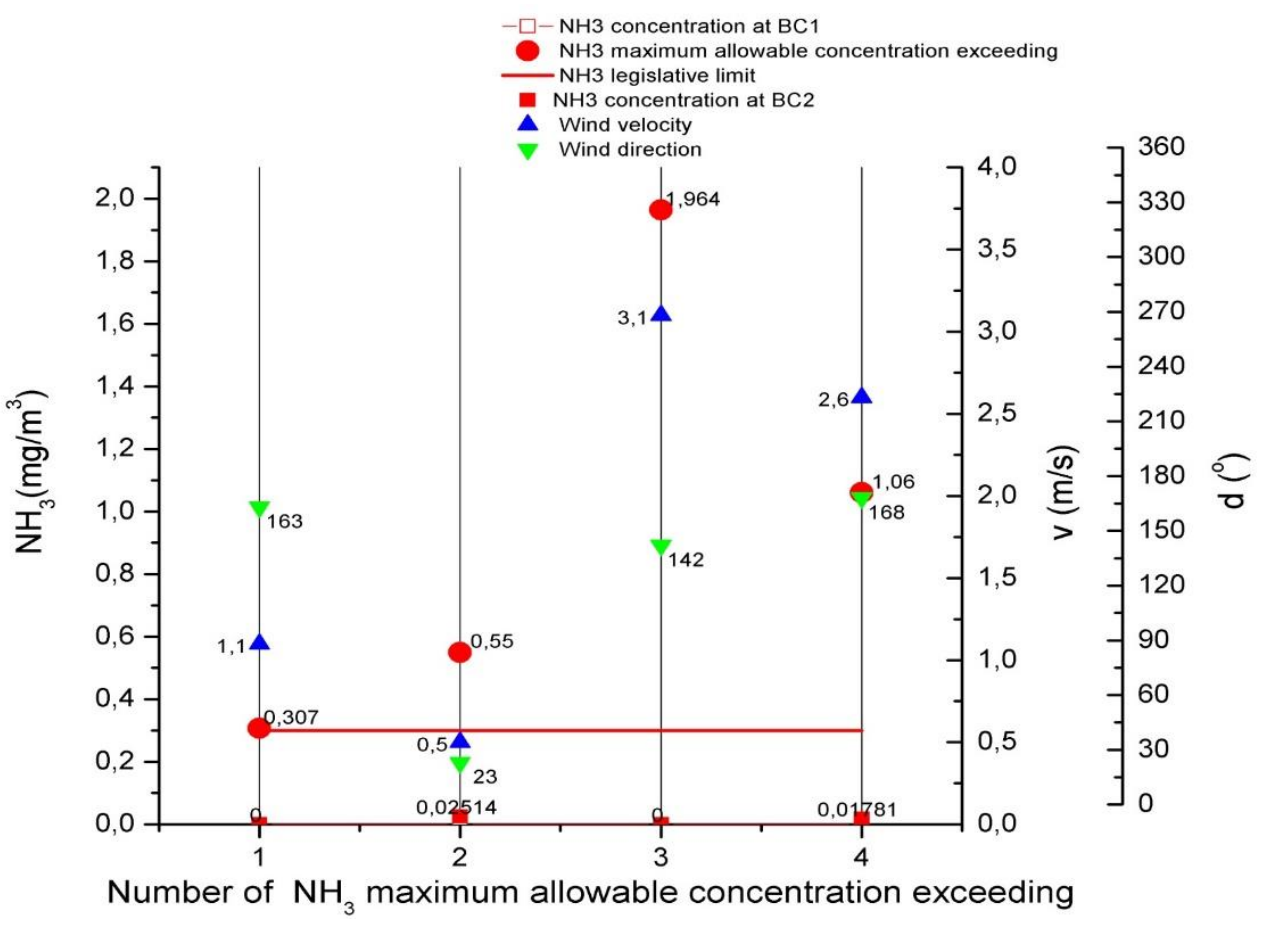

Fig. 7.Maximum allowable concentration overruns for ammonia $\left(\mathrm{NH}_{3}\right)$ in the air, the wind speed (v) and direction (d), in 2008 at the air quality monitoring station BC 2 (Izvoare) [4].

Air temperature values oscillated around the average monthly maximums multiannual with deviations of $\pm 3^{\circ} \mathrm{C}$. Atmospheric pressure has been similar to those of normal values. From the analysis of relative humidity distribution (Figure 6) it was found that values of this meteorological parameter are situated between $50-70 \%$, which correspond to a normal air. At the same time, as the solar radiation has higher values, over $400 \mathrm{~W} / \mathrm{m}^{2}$, the ammonia concentration values are lower [4].

During 2008 has been found that wind (Figure 7) had predominantly southern direction, with values up to $2 \mathrm{~m} / \mathrm{s}$, which generally correspond to weak wind.

\section{CONCLUSIONS}

For case study was chosen Bacau area, which present particularities both geographical (hilly area with pronounced valleys, confluence of the most important rivers from Moldova region etc.) and industrial (Bacau is an industrial city). Given the particularities of Bacau area (climatic factors and environmental), are necessary the monitoring methods of the interaction between them and establishing human and environment effects [4].

Present study tried to establish correlations between industrial quality environment and climatic factors variation(wind, atmospheric humidity, solar radiation, atmospheric pressure, nebulosity) on ammonia $\left(\mathrm{NH}_{3}\right)$ concentration [4].

On the grounds of the here discussed data it can be said that MAC overruns for ammonia corresponded to the following meteorological conditions: atmospheric pressure has registered value closed to the normal; solar 
radiation evolved to maximum values; humidity marked low values, below $60 \%$; windblown weakly towards the southern sector. Moreover, duration of sunshine over a longer period, without or with low nebulosity, showed a great importance in term of atmosphere pollution. In these conditions a better dispersion of pollutants occurs, resulting in a lower degree of atmospheric pollution. This conclusion is supported by the data about ammonia trend observed on 2008.08.20 [4].

\section{REFERENCES}

[1] Allaby, M., Atmosphere: A scientific history of air, weather and climate, Facts On File Inc. PublishingHouse, New York, 2009.

[2] Capşa, D., Barsan, N., Felegeanu, D., Stanila, M., Joita, I., Rotaru, M., Ureche, C., Influence of climatic factors on the pollution with nitrogen oxides (NOx) in Bacau City, Romania, Environmental Engineering \& Management Journal, vol. 15 no. 3, 2016, p. 655-663.

[3] Capsa, D., Nedeff, V., Barsan, N., Climatic factors influences to the ammonia air pollution, case study 2009 Bacau City Romania, Academic Journal of Science, vol. 3, no. 2, 2014, p. 97-106.

[4] Capsa, D., Studii și cercetări privind variaţia calității mediului industrial în corelație cu factorii climatici, Teză de doctorat, 2015, Universitatea "VasileAlecsandri" din Bacau.

[5] Capşa, D., Nedeff, V., Faciu, E., Lazăr, G., Lazăr, I., Bârsan, N., Aspects of the fog phenomenon in Bacău city, Present Environment and Sustainable, Development, vol 6, no.1,2012, p. 325 - 340.

[6] Capşa, D., Nedeff, V., Vasilică, M., Lazăr, G., Panainte, M., Bârsan, N., Extreme temperatures and their effects on the human body, Present Environment and Sustainable, Development, vol.,6, no 2, 2012, p. 387-404.

[7] [http://www.intechopen.com/books/air-quality/methods-for-online-monitoring-of-airpollution-concentration (15.05.2011)

[8] Nedeff V., Măcărăscu B., Geamăn V., Ingineria si protecţia mediului in industrie, Editura, Tehnica-Info, Chişinău, 2003.

[9] Vallero, D., Fundamentals of air pollution, 4-th edition, Ed. Academic Press, 2007.

[10] Iojă, A.D., Calitatea mediului în spaţiile rezidenţiale din municipiulBucureşti, teza de doctorat, 2009, Universitatea din Bucuresti Facultatea de Geografie.

[11] http://www.mmediu.ro/beta/domenii/protecția-atmosferei/calitatea-aerului/ (18.11.2011).

[12] Teodoreanu, E., Climate and human friends or enemies, Publishing House PAIDEIA, 2011.

[13] Ciulache, S., Influenţa condiţiilor meteorologice şi climatice asupra poluării aerului, Com. Geogr., V, Ed. Univ. Bucureşti, 2004.

[14] http://www.epa.gov/ncea/isa (19.07.2010).

[15] http://www.eea.europa.eu/ro/themes/air (29.03.2012

[16] Beaumont, L.J., Hughes, L., Poulsen, M., Predicting species distributions: use of climatic parameters in BIOCLIM and its impact on predictions of species' current and future distributions, Ecological Modelling, vol. 186, no. 2, 2005, p. 251-270.

[17] Sonal, S.V., Birva, D., Effect of meteorological conditions on air pollution of surat, Environmental Application \& Science, vol. 3, no. 5, 2008, p. 358-367.

[18] http://www.euro.who.int/ data/assets/pdf file/0009/128169/e94535.pdf (12.03.2010).

[19] http://eurlex.europa.eu/LexUriServ/LexUriServ.do?uri=CELEX:32004L0107:en:NOT (20.05.2010).

[20] http://eurlex.europa.eu/LexUriServ/LexUriServ.do?uri=OJ:L:2008:152:0001:0044:EN:PDF (07.08.2010).

[21] http://www.calitateaer.ro/indici.php (12.08.2010).

[22] GuvernulRomâniei, Legeanr. 104 din 15 iunie 2011 privind calitatea aerului înconjurător, 2011.

[23] Guvernul României, Monitorul Oficial Ordin nr. 592 din 25 iunie 2002, privind stabilirea valorilor limită, valorilor de prag şi a criteriilor şi metodelor de evaluare a poluanţilor din mediul înconjurător, 2002.

[24] http://www.calitateaer.ro/structura.php (12.09.2011).

[25] Pal A.S., Air polution meteorology and dispersion, New York: Oxford University Press, 1999.

[26] Răducan, G.M., Contribuţii la studiul variabilităţii spaţio-temporale a poluării aerului, Teză de doctorat, 2008, Universitatea Bucureşti, Facultatea de Fizică.

[27] Administraţia Naţională de Meteorologie, Clima României, Editura Academiei Române, Bucureşti, 2008.

[28] Ştefan, S., Fizica atmosferei, EdituraUniversităţii din Bucureşti, Bucureşti, 2004. 